\title{
In support of female leadership in the church: Grappling with the perspective of Setswana men - Shepherding as solution offered
}

Authors:
Gopolang H. Sekano ${ }^{1}$
Maake J. Masango
Affiliations:
'Department of Practical
Theology, University of
Pretoria, South Africa
Correspondence to:
Maake Masango
Email:
maake.masango@up.ac.za
Postal address:
PO Box 84173, Greenside
2034, South Africa
Dates:
Received: 17 Sept. 2010
Accepted: 04 Aug. 2011
Published: 27 Mar. 2012
How to cite this article:
Sekano, G.H. \& Masango,
M.J., 2012, 'In support of
female church leadership:
Grappling with the
Setswana male perspective
- Shepherding as solution
offered', Verbum et Ecclesia
33(1), Art. \#433, 8 pages.
http://dx.doi.org/10.4102/
ve.v33i1.433

ve.v33i1.433
C) 2012. The Authors. Licensee: AOSIS OpenJournals. This work is licensed under the Creative Commons Attribution License.
This article addresses the overwhelmingly negative experience and feeling of some men who serve under female leaders in the church. They claim to feel degraded and traumatised by the experience of being led by women. They also claim that their patriarchal culture and religion is defied by such actions and laws of equality that encourage female leadership. They substantiate their views by quoting 1 Corinthians 14:34-35 and 1 Timothy 2:12-14 in addition to a Setswana proverb, 'Tsa etelelwa pele ke e namagadi di wela ka lengope' [those who are led by a female leader fall into dongas]. In the light of this situation an intensive study regarding the need for an egalitarian concept and constructive interpretation of Bible passages, Setswana proverbs and idioms regarding the inevitability of female leadership is paramount to people who have an androcentric concept of religion and culture.

\section{Introduction}

One wonders what it is that causes men to be stressed up to the point of withholding their support for women who are given the responsibility of leadership, especially in the church. Why do men who serve under female leaders quit their position and cause regression in their churches?

Most South African men are brought up in a patriarchal mould. This kind of cultural upbringing is reproduced by the entire societal-institutional spectrum, in church, school, home and work place. These institutions enhance and support patriarchy and its structures and thus sanction women's oppression.

In our age not only South Africa but also the world is moving towards non-racial and non-sexist approaches to society. Nevertheless, traditional male-orientated society is still captivated by patriarchy, in this context expressed by a lack of acceptance that women will ever make good and capable church leaders. This notion exists in their minds, even though the forums for equality may encourage the opposite.

The great concern is that the large majority of men who hold this opinion are members of churches (denominations), and some are even clerics. The basis of their argument is founded in selected biblical passages coupled with patriarchal informed cultural wisdom derived from Setswana proverbs and idioms. Examples of this would be the response of the author of the 1st letter to the Corinthians that is as follows:

Let your women keep silent in the churches, for they are not permitted to speak, but they are to be submissive as the law also says. And if they want to learn something let them ask their own husbands at home. For it is shameful for a woman to speak in the Church. (1 Cor 14:34-35)

In the letter to Timothy, it reads:

(...) and I do not permit a woman to teach or to have authority over a man; she must be silent. For Adam was formed first, then Eve. And Adam was not the one deceived; it was the woman who was deceived and became a sinner. (1 Tm 2:12-14)

These passages are contextually referenced by establishing a connotation to the aforementioned Setswana proverb. This negative proverb reinforces and encourages the continued socialisation of men towards female leadership. This allows men to feel justified in negating the authority and leadership of women in the community. Some of the men who find themselves under the leadership of women withhold their support and cooperation with these women, whilst some men even quit their jobs and church affiliation. These actions cause tension in working places, particularly in the church. The methodology that is seen as a solution is the shepherding motif according to Campbell 1986 and Gerkin 1997, with emphasis on caring, oneness and learning. Concerning shepherding, Campbell (1986) says the following: 
The positive attributes of the good shepherd are given prominence and are used to express the loving leadership of God and of His promised Messiah. The shepherd leads, guides, nurtures, heals, seeks out the lost, brings the scattered flock together and protects it from harm. (p. 28)

This motif encourages pastoral caregivers to desire to learn in order to properly guide the people of God in their needs. The saying that leaders will only be able to lead up to their state of understanding or ability is quite applicable in this debate. You cannot offer that which you don't have. All the characteristics and attributes of the shepherd cannot be functional if learning is not emphasised and practiced, therefore Waruta and Kinoti (2008) quote Obeng as follows:

Obeng is critical of the current theological training in Africa, which has so far tended to lay emphasis on spiritual leadership and discouraged critical thinking. He advocates for the kind of training that will take into account the problems and challenges of contemporary society (...). Particular emphasis on four aspects which are of great relevance in contemporary Africa - interreligious dialogue, African religion and culture, social concern and counselling services. (pp. 8-9)

Therefore pastoral caregivers must aspire to understand the times they live in, in order to positively interpret them. This means to understand the situation the people who are under their care are going through and to get a solution to their problems. This can be possible if proper training, as mentioned earlier, is acquired. This aspect of understanding the times has been captured more than once in the Bible, therefore the authors deem it as essential (see $1 \mathrm{Chr} 12 ; 32$ \& Mt 16: 2-3; 24:3).

A caring shepherd should always be willing to assist troubled souls, in order to make this changing world a better place to live in. Gerkin (1997:112) outlined the five congregational dimension of shepherding in the following ways:

- the community of language

- the community of memory

- the community of inquiry

- the community of mutual care

- the community of mission.

Any institution that wants to prosper (or care for others) in its mission needs these dimensions as support pillars. Language is a form of identity. It enshrines the culture and custom of a group of people living together. Speaking the same language means to agree or to understand one another. The church as a community of language is expected to speak in one voice against all forms of oppression and injustice to all people, irrespective of gender or race. The community of memory is the past experience that a group of people have gone through. It helps people to share the past, whilst demolishing the unprofitable and upholding the profitable for a better future. The community of inquiry refers to an institution that seeks clarity especially on past and present issues in order to properly plan the future. The community of mutual care is a group of people who look after each member of the group. That means doing unto others what you want them to do unto you, in the biblical language (Mt 7:12). The community of mission is a group that is determined to finish the task assigned to it.
Through the aforementioned dimensions, the pastoral caregivers can develop lessons and sermons that can help men who feel degraded, because of serving under women, to come to the understanding that women are also called and filled with the Holy Spirit of God. The Spirit that gives different gifts such as, for example, teaching, pastoring, prophesying andevangelising. If God had once used a donkey as an instrument to convey a message, surely female leaders are worthy to be used by God? This statement is a great challenge for patriarchal men who would not allow women leadership within the church. Such men can be taught that women are co-labourers with them in the field of God and that they are all assigned with the mission to share the gospel with all human beings. According to the gospel of Matthew, it was women who first met with Jesus Christ after his resurrection, and were given the instruction to take the gospel of his resurrection to his disciples (Mt 28:5-10).

\section{The experience of men under female leaders}

Men are said to feel humiliated by being made equal to their female counterparts, or put under their direct authority. The article 'Woman chief dents egos' from the Sowetan newsletter, confirms the negation of women leadership by men as follows:'It is against our tradition to have a female Chief', spokesman for the group Ishmael Risivi told Sowetan. 'We don't care about her victory from the highest court of the land. 'We believe he who would be chief should be installed according to the tradition and custom of the Valoyi tribe and not through a piece of paper', Risivi said. (Matlala 2008:3)

During 2001, the first author attended a couples' seminar where some men raised their concern regarding their experience and feelings under the leadership of women at their work places. They felt degraded by taking orders of work from women and they interpreted equality as violation of their culture and of the Word of God. They substantiated their 'facts' by quoting 1 Corinthians 14:34-35 and 1 Timothy 2:12-14 as well as the Setswana proverb that has already been referred to (those who are led by a female leader fall into dongas).

Concerning the issue of cultural upbringing, Waruta and Kinoti (2000) say the following: 'Most people are moulded by the type of education they are exposed to during their training' (p. 16).

In concurring with Waruta and Kinoti (2000), the authors share the fear that many men are captives of their upbringing. The authors have developed their argument in order to show that prejudices are a result of what a person is exposed to. These prejudices can be dangerous, both for the person who holds them and to the person who is a victim of them. However, the authors are convinced that it is possible to turn over a new leaf through positive learning. The former president of South Africa, the Honourable, Thabo Mbeki, delivered the message of renaissance to South Africans, which requires people to change for the better. 
As a young Motswana person, the first author's father and uncle taught him to behave like a man -and not like a woman - and that whatever he did was to be outstanding when compared to girls. He was expected to be brave and wise. Any weakness or failure was associated with girls or women and would result in being mocked with words like 'Kentse ke go bona gore o apere mosese kgotsa bulumase' which translates as 'I have seen that you are wearing a dress or panty (women's underwear)'. These words made him feel very small and very angry. The idea that men are better people than women was also supported by the community.

It was staggering that even the female class teacher of the first author had the same mentality. When boys performed poorly in a test compared to girls, she would say, 'Sis! Letlhabisa ditlhong, o ka re ga le basimane. Le gaisiwa ke basetsana, le tla nna jang ditlhogo tsa malapa le le dielele. Basadi ba lona batla lo goga ka dinko', which translates as 'You boys are a disgrace; the girls have done better than you. How will you be heads of households when you are stupids? Your wives will pull you by the noses'. The issue of female leadership was not only challenged by the community but also at a primary school level. The authors wish to demonstrate how this concept is emphasised, perpetuated and pushed onto boys whilst they are young; even by female authority figures. This kind of upbringing resulted in the first author having a negative attitude towards woman. Even when he was motivated to complete a task, he did his best to outsmart the girls. He had a strong need to feel superior because he was taught that boys are better than girls, and that boys were masters and girls were servants.

In complimenting the aforementioned statements regarding the mould, the authors quote the words of Baloyi (2007):

The preaching points of the church in which the researcher is serving are now closed (...) the women claimed that they cannot go to church without a male preacher every Sunday because they had been taught from long by the missionaries that the Bible wanted only men to take the lead in the church (...). The elders of the church confirmed that, that was the way things should be. They believed in men being the head of a woman. (p. 5)

During 1985, the chief of one of the northern villages in Rustenburg, in the North West Province, passed away. His wife could not take over the throne to lead because she was a woman. The younger brother of the chief was forced to relinquish his work, in order to take the chieftaincy of the tribe. He lacked leadership skills, but because he was a man, he was crowned the chief of the tribe. This is an example of some customs that inhibit men from allowing female leadership, let alone African proverbs, idioms and customs rooted in villages (Personal communication).

The widow of the deceased chief had skills because of the leadership experience she had gained from her husband whilst he was still alive. The tribe lost an experienced person because of the patriarchal concept that destroys female leadership. The same mentality is seen in some denominations. Male pastors are treated with great respect; they are given front seats at the podium whilst their wives are left behind. This is a clear indication that pastors' wives are not considered as co-leaders with their husbands. What is more disturbing is that even female pastors are not given preference when compared with male pastors (see Snyder \& Runyon 1986:99).

In view of the aforementioned information, it should come as no surprise that men from traditional society feel degraded by the new laws of human rights and gender equality depicted in the 1996 constitution of South Africa, which they view as negating the law of God and of their culture, by giving women the opportunity to fulfil leadership roles in the community. According to traditionalists, a woman's primary duty is to take care of the home, under the undoubted male authority.

As much of the aforementioned approach purports to be based on the reading of the Bible, we argue that selected Bible passages be revisited, and possibly reinterpreted as a means of changing attitudes for the better. Given the accepted authority of the biblical text, the endeavour would be to emphasise an alternative interpretation not based on a passage, but on a general overview best summarised by the question: What does the Bible have to say about the leadership of women?

For centuries patriarchy has been pervasive and most women and children were discriminated against because of it. It has been an enemy to justice and fairness, and must not be allowed to be practiced any more. Those who are entrapped by patriarchy must be freed. Fiorenza (1996) has the following to say regarding this topic:

As long as patriarchy endures, an ecology that leads to change is impossible (...). Ultimately patriarchy is not something predestined but a historical phenomenon. It arose at some time; it can also disappear again. And it is now the time for that (...). (pp. 138-140)

The South African government, through its constitution, is also challenging this concept of oppression. The month of August is dedicated to women, and its ninth day is National Women's Day in South Africa. Seminars are held country wide to upgrade the status of women and they are encouraged to claim their democratic rights. To substantiate this statement, the Gauteng Provincial Government newsletter (2008), through the then Premier, reported as follows:

Premier Mbazima Shilowa said the government had created a new order where women participate as equals and their voice was heard in all decision-making structures. 'We need to ensure that women also become accountants, engineers and successful business people,' said Shilowa. (Sic) He noted that in the remaining period of his term his government will strive to have: $50 \%$ appointment of women in senior management positions (...). (p. 1)

The government has also noticed the injustice that is taking place in the church regarding leadership and responded in the Daily Sun (10 July 2008) newsletter as follows:

Women are equal! Religious leaders in Africa must stop treating women as if they are inferior. This was said by Limpopo 
Legislature speaker Dr Tshenuwani Farisani (...). He will be presenting the keynote address and challenging African religious leaders to treat women as equals. 'There are still certain religious practitioners who find it difficult to accept that women have the same rights as men. Such unlearned practices are harmful to human rights and gender equity', he said. (p. 15)

\section{Top church elders quit}

It is now over a decade since the first author's church started to ordain female pastors. It is clear that some men are not comfortable with female leadership. Other denominations are completely against the ordination of women to priesthood. Karant-Nunn and Wiesner-Hanks (2003) say the following:

Churches today-both Protestant and Catholic, as well as Jewish, Muslim and other religions-are still wrestling with the balance between men's and women's spiritual equality and social difference. (p. 8)

In the year 2000, the first author was transferred from the church he was pastoring. The church was doing well and had the potential to grow numerically, financially and spiritually. He had two strong and staunch male elders whom he considered pillars of the church. They supported him in all church duties. Since he was the pastor of two different local churches, he depended strongly on them to run the respective church when he had to go to the other church. His replacement was a woman who was very gentle, yet strong in her leadership and church duties. After a few months, the female pastor told the first author that the chief elder and chief deacon were dragging their feet when executing church duties. Before long he was informed that the top elders and their families had left the church. Their reason for leaving was that they did not feel comfortable with the new female pastor. The issue was that a woman was playing the leadership role. They could not take instructions from a woman.

These issues reminded the authors of their past experiences and reminded them how men who are brought up in a patriarchal system do not respond positively to changes of structures in leadership. Our churches cannot afford to lose skilled and experienced men who are resigning from their positions because of the transition to a non-sexist society, hence the need to educate those who are entrapped in the patriarchal system. Our country will not be democratic until all its citizens are treated fairly and justly (equally) without any prejudice.

The prosperity of our churches, places of employment and homes depends upon the law of equality (see the Constitution of RSA 2005:6-7) whereby no one will be discriminated against irrespective of gender or race. Reuther (1993) says the following:

The church must reform its patriarchal structures to include women's right to full participation in all leadership roles (...). The church as bearer of redeemed humanity ought to represent especially this equality of men and women in its institutional life. (p. 104)

\section{Perplexity in transformation}

Most changes cause a certain amount of fear and confusion to the affected people if they are not properly prepared for them. It comes as no surprise then that some of the men at the couples' seminars (mentioned in an earlier section of this article) raised their concern and said: 'This world is becoming the world of women'. The Valoyi tribe as cited in an earlier section of this article, challenged the court verdict that favoured a woman to be chief of the tribe. The confusing factors here are that men are culturally and biblically heads and leaders whilst women are subjects. Yet constitutionally, men and women are equal.

To a certain degree, this might have been the cause of the reaction of the council of traditional leaders regarding the law of equal rights to all South Africans regardless of gender or race. Brimohanlall et al. (1999) report as follows:

During the drafting of the final constitution, the council of traditional leaders of South Africa responded furiously to criticisms of this practice and lobbied to have custom override the right to equality. They claimed that this 'western' notion would undermine long established and respected custom. This attempt did not succeed because the right to equality enjoys superiority over the right to custom. (p. 75)

Such men, who are the products of patriarchy, are found to be trapped in it; hence they feel degraded and traumatised by having to take orders from women. The culture that has always elevated them above women is crumbling down and this is of a great concern to them. Some have to take orders from single young women, something which the men experience as extremely traumatic. They say, 'Go etelelwa pele ke basetsanyana go re dira e kete re tsamaya re sa tswala', which translates asbeing led by young girls makes them feel as if they walk around naked. Such idioms play an important role in hardening the hearts of men, especially when it comes to female leadership.

Concerning the equality of people, Brimohanlall et al. (1999) quote the new constitution of South Africa:

Everyone is equal and has the right to equal protection and benefit of the law. No one including the government is allowed to treat you less well than other people because of your race, gender (...). The right to equality is recognized as one of the most important and basic rights of our constitution - especially because of South Africa's brutal apartheid past, based on opinion of inequality. We must assess what seems to be conflicting laws to find out if they oppose the right to equality (...). (p. 80)

The types of male leaders that have been discussed in this article thus far do not support this new concept of equity law, and this affects the progress of some institutions, especially churches. Men are generally more experienced in most fields of work because of past inequality. As a result women who have obtained leadership positions need the support, help, skill and knowledge of the men who had been there for years, in order to show progress. If these women are refused such support and exposure, they will fail in their duties, and the response will be 'Re ne re ka makala ga mosadi a 
ka kgona se', [we would have been surprised if a woman could have managed this]. The main problem is that some of the women in the church will believe the aforementioned statement, internalise it and live according to it. The culture and community will re-enforce it as a part of life.

An educational process is needed amongst women in order to empower them by means of a a shepherd who believes in their leadership skills. This can take place through, for example, inviting motivational speakers to speak on topics like self esteem, women and leadership, transformation, to name but a few. Churches are divided on the issue of female leadership. Great wisdom is needed in order to harmonise institutions that do not speak one language of fostering equity law within their perimeters. The Prophet Amos says, 'Do two walk together unless they agree to do so' (Amos 3:3). For any institution to progress, unity is paramount. A paradigm shift is required within the church. This institution is capable of changing the mindset of men and the community.

Men who are caught up in their cultural upbringing must be helped to be freed from it and adapt to a society that is not sexist. A second paradigm shift is needed in communities who believe in the negative proverbs and idioms (mentioned earlier in this article). Some men do not support female leaders, rather they make it difficult for them to become competent leaders. Because some Bible passages have the same connotation as the aforementioned proverbs and idioms, they tend to exacerbate the whole issue around the idea of women becoming leaders. Paul wrote to Timothy regarding leadership of women as follows: 'I do not permit a woman to teach or to have authority over a man; she must be silent. For Adam was formed first then Eve' (1 Tm 2:12-13).

The fact that other scripture passages on the leadership of women are ignored causes the misinterpretation of the aforementioned scripture to a point that some men become instruments of oppression within the body of Christ. That Adam was formed before Eve cannot be disputed, but that does not make her or any other women a lesser person, when compared with Adam or men in general. The correct interpretation of the aforementioned passage was that Paul was declaring order in the church, because of the misconduct portrayed by some women.

However this should not only apply to women but to all people (who disrupt proper church service) regardless of gender or race.

\section{The need for positive interpretation}

It is imperative that the negative interpretation of proverbs, idioms and Bible passages be annulled in order to mould a positive and productive community. Interpretation as a discipline is important because meaning has to do with the core of human beings' thinking. The need for interpretation is not peculiar to the scriptures. Any document, ancient or modern, must be interpreted (see Snyder \& Runyon 1980:96).

\section{Proverbs and idioms}

In Setswana idioms are called 'maele', which means 'advices', whilst proverbs are called 'diane', which expresses a basic truth or a practical precept. Therefore, the idiom and proverb, which will shortly be given, are advisory and destructive according to the authors.

'Tsa etelelwa pele ke e namagadi di wela ka lengope' translating as 'led by a woman they fall into dongas' and 'Go gogwa ke mosadi ka nako' [woman pulls you by the nose] refer to when a woman has control over a man. Normally this idiom is used when a man is too agreeable with whatever a woman is saying, regardless of whether it is right or wrong. These sayings are intended to demoralise the man it refers to. Therefore these idioms and proverbs are seen as negative; they associate femininity with weakness and incapability to lead, or create strife between men and women. These kinds of African idioms and proverbs are used as a way of dehumanising women.

Even though most idioms and proverbs are derived from past experiences and the observation of events, constructive ones should be used instead of the destructive ones, for the betterment of the church and the community as a whole. A proverb such as 'Mosadi o tshwara thipa ka fa bogaleng' [a woman holds a knife on its sharp side] means that a woman is brave to a point of getting into danger in order to save the situation. For example, Esther went into the king's courtyard when she was not supposed to and said that if she perished, she perished because she could not watch the Jews being annihilated. Such proverbs can revive the self-esteem of women and at the same time break the superiority complex in men.

Concerning proverbs and idioms, the authors of 'Musupatsela', Nkotsoe, Phage and Rakgokong (1998:154) state: 'Seane ke polelwana e nnye mme e le boteng, e thagisa bokao ba nnete le go naya botlhale (...)'. This means that a proverb is a short figurative sentence that gives true meaning and wisdom. Historically, women were denied the opportunity to study and take part in leadership practices, and were demoralised by such proverbs and idioms. It might be true that certain women were bad leaders in the times when the idioms and proverbs were created, but it would have been because they were denied the opportunity to learn how to lead. Women are growing into outstanding leaders because doors to leadership are opening, although they are very slow and discouraging at times.

Based on the aforementioned articulations the authors concur with Nkotsoe et al. (1998) in part, because proverbs such as 'Tsa etelelwa pele ke e namagadi di wela ka lengope' [those who are led by a female leader fall into dongas] contain no truth, because a number of women are in leadership and are doing well, therefore it is bad advice. In the following section we will provide some examples to substantiate this claim. 


\section{Biblical passages}

Concerning interpretation, Paul commanded Timothy to handle the word of God with great care by saying: 'Do your best to present yourself to God as one approved, a work man who does not need to be ashamed and who correctly handles the word of truth' (2 Tm 2:15).

Mickelsen (1963) says the following regarding this interpretation:

The interpreter must have pure motives; he (sic) must speak as one send from God. He (sic) must present his (sic) conclusion before God. He (sic) must do all these with awareness that he (sic) is bound to Christ. (p. 4)

All biblical interpretations have two dimensions. The first is concerned with discovering the meaning of a statement, whilst the second takes account of changes in meaning, which contemporary readers may attach to the same words. One valid principle of determining the meaning of a word is to study the context as well as the usage of the meaning which the word is known to have in other contexts. Mickelsen (1963) states:

Interpretation could be literal, allegorical, moral or anagogical. Jerusalem for the medieval interpreters could refer to the literal city in Palestine. Allegorically it could mean the church. Morally (Topologically) it could refer to the human soul. Anagogically 'Jerusalem' refers to the heavenly city (...) the literal meaning is plain, evident meaning, the moral sense tells men what to do; the allegorical sets forth what they are to believe; Anagogical centers in what Christians are to hope. (p. 35)

He further elucidated the five principles for interpreting from context (see Michelson 1963: 113). Men who raise the concern that the world is becoming the world of women, and that their culture and the Word of God is being defied quote 1 Corinthians 14:34-35; 1 Timothy 2: 11-14 and the Setswana idiom that has already been shared. Some men interpret the aforementioned scripture passages literally without understanding the context.

Historically, the church has always been very focussed on what is and was seen as the proper order of things. A good example is seen in how Paul, as a senior pastor, used his own discretion to enforce order. Williams (1978) describes the situation as follows:

The command to women to be silent during worship in Corinth arises because "The women were interrupting the meeting with questions'. The prohibition over women teaching men in 1 Timothy 2:12 reflects a concern for maintaining the cultural status quo, for not transgressing the marital social roles. (p. 25)

It is clear that the only remedy to the confusion and pain that is caused by patriarchy, to both the oppressed and the oppressor, is an intensive positive education, for education is power and power liberates. Education that will be part of therapy should, for now, start with stressed and degraded men serving under women leaders. Such men find themselves caught between these concepts of patriarchy and equality. Within patriarchy these men are taught that a man is superior to woman and it is disgraceful, if not a taboo, for a man to be led by a woman, whilst the law of equality teaches that both men and women are equal and have the same rights.

On 10 August 2008, the church in which the first authorserves as a pastor was commemorating Women's day. The topic was 'Women are powerful' and the preacher was preaching about women who used their power constructively, like Deborah who led the Hebrews to victory, Esther who was prepared to die for the sake of her people and South African women who bravely marched to the Union Building in Pretoria negating the pass law in August 1956.

He encouraged women to stand their ground and claim their rights. After the sermon the pastor's assistant, who is a woman, shared her bitter experience of being refused to preach in the pastors conference, to which she was invited. This happened simply because she is a woman. The male pastors who called for her descent from the pulpit capitalised on the very Pauline letters like the rest of the men. Firstly, this proves the danger of literal interpretation and of formulating a doctrine without considering all relevant texts. Secondly, these men consider themselves as the defenders (apologists) of scriptures and their culture.

The concept of male dominance has negatively affected most African men. The patriarchal mould has shaped them and for some men it is not easy to adapt to the new changes of equity law. The author substantiates the aforementioned statement by quoting Brimohanlall et al. (1999) when they say the following:

Male privilege is basic to our society (...) every advantage for men is made possible (...) men are superior to women (...) to patriarchy which sees men as rulers making decisions for women and children. (p. 22)

Not all women are weak and incapable to lead; there are also some men who are weak and incapable. This means such people are not supposed to lead - not because of their gender - but because of their inability. Nabal, the husband of Abigail was unable to head his house well because of his surliness, meanness, wickedness and drunkenness, therefore his wife Abigail took the lead of interceding for their family to be spared (1 Sm 25:2-39).

\section{The perception of men serving under female leaders}

This article aims to address the experience of men who claim to be degraded by serving under female leaders in the church, and because of cultural upbringing, end up withholding their support and obedience to such female leaders. This results in the regression of the church. The reader should now understand why men, who are products of negative patriarchal concepts - as the authors were before undergoing theological training - , need to be helped to turn a new leaf. Fostering intense education is the only remedy for this warped ideology of subjugating women in the name of God. 
The authors substantiate the aforementioned statement by borrowing the words of Kung (2001):

For a long while it was taken for granted that the subordination of women desired by the church was legitimated by divine revelation and scared tradition and this is still the position of some clergy (...) and elsewhere. (p. 17)

It is also clear that it is not only the Pentecostal Holiness Church that is a captive of androcentrism, but also a number of other churches, especially some indigenous African ones, because of a strong cultural background, upbringing and literal interpretation of the texts in question. The church of Jesus Christ is the community of equal discipleship, which Fiorenza (1990) elucidates as follows:

Structures of domination should not be tolerated in the disciple of equals, but those who 'would be' great or first among the disciples must be a slaves and servants of all. (p. 147-148)

Pastoral caregivers should develop lessons on outstanding female leaders and men whose focus were on competency and not on gender. Churches should make theological training an obligatory qualification to pastor-ship, especially on the subject of gender, as in the Pentecostal Church some pastors are not theologically trained. By doing this many flaws or misinterpretation of scriptures will be avoided, and church members will be properly informed. The Christian or Jesus culture should be a supra culture and give direction to other cultures not the other way round.

\section{Propagation of positive change to all stakeholders}

Some men and women, both leaders and subordinates, are captives of patriarchy and must be liberated from this destructive view. Liberation will only be possible if intense education is fostered. Women are taught to submit and to be followers of men, whilst men are taught that they are leaders according to God's purpose and the Setswana culture. In Setswana culture women are treated as children, regardless of their age, and children are expected to be submissive to their parents (men). Because of this, men feel degraded when women become leaders.

It is because of the aforementioned reasons that a positive change, which should not be based on emotions, but on facts and honesty, be fostered, as emotions are not always reliable. A lesson on outstanding women leaders should be developed by pastoral caregivers in order to convince men that women are capable to lead. This kind of a lesson will also motivate female leaders who were demotivated because of the negative response of men towards their leadership. To help men who feel degraded by serving under women leaders, enlightenment is paramount. The authors substantiate this claim by borrowing the words of Herman: 'The central part of therapy should always be to enlighten the patient as to the nature and meaning of his (sic) symptoms' (2001:135).

This will only be possible if the pastoral caregiver can journey together with these men who feel degraded and stressed so that the ability to diagnose will fall into place. Once diagnosis has been made, treatment towards healing is possible. In this case the symptoms are 'fear' that the institution will collapse because of the poor ability and inexperience of women to lead and a 'superiority complex'.

Examples of relevant lessons that can bring healing to such men could be planned in the following way:

- equality and companionship of man and woman (Gn 1:26-28; Gl 3:26-29)

- men and women endowed with the Holy Spirit (Jl 2: 27-29)

- men and women dependent upon each other (1 Cor 11 4-9)

- Biblical and politically outstanding female leaders such as Anna (Lk 2:36-38), Deborah (Jude 4: 4-9), M. Thatcher, N. Dlamini-Zuma, P. Mlambo Ngquka (outstanding female church leaders include G. Copeland [USA], C. Kullman [USA] and Dr Seobi [RSA]).

\section{Reviving trained pastors}

Pastors are charged with the high responsibility of caring for the sheep of Jesus Christ to a point of dying for the flock or a single sheep. Pastoring people is a high calling that must not be treated lightly. Just like Moses, pastors must stand in the gap between the weak, down trodden and the strong. In the book of Exodus, Moses was an outstanding model of a true leader. He stood before Pharaoh negotiating the release of the Hebrews.

\section{Encouraging untrained pastors}

The words 'Nemo dat quod non habet' [You cannot offer that which you do not have] are appropriate for this section. The indigenous churches will suffer and as a result affect main line and Pentecostal churches if we do not help to teach and shepherd them, and to create sound and unbiased leadership. The skill of shepherding is acquired through training. Pastors must be knowledgeable through the processes of education in ministry in order to be good shepherds. Some theological institutions have developed distance learning (TEE Theological Education by Extension) in order for those who cannot attend full time training to have an opportunity to study. As we deal with this problem of undermining female leadership, we need to move the church, community and male leaders into an era of enlightenment regarding equality and fairness irrespective of gender, race or colour.

Learning will minimise or annul interpretation flaws, and build the self-esteem of the pastors who will in turn be able to relate to women as equal partners. This process will challenge patriarchal structures that are difficult to change.

\section{Model}

The authors explored and addressed the experience of men who serve under female leaders and sought a model that could create harmony between them. 
The authors have made some recommendations on how female leadership can be encouraged and supported in churches. Firstly, it can be obtained by encouraging trained pastors, to courageously take their rightful stand of offering positive and relevant lessons that can bring a new culture of comradeship. Secondly, to discourage and to annul negative Setswana idioms and proverbs, and the negative interpretation of some of Bible passages such as the Pauline Letters indicated previously. Thirdly, to teach about government laws that condemn human abuse and discrimination, and lastly, to propagate equality, in order to pave the way for an egalitarian style of leadership.

The egalitarian style of leadership is a kind of leadership that believes and propagates equality in leadership regardless of gender or race. It maintains the belief that all people are in principle equal; therefore, they must enjoy equal rights and opportunities, with competency as a criterion to leadership. This principle is seen in Genesis, when God says:

Let us make man in our image, in our likeness, and let them rule (...). So God created man in his own image, in the image of God he created him; male and female he created them. God blessed them and said to them, 'Be fruitful and increase in number, fill the earth and subdue it'. (Gn 1:26-28).

\section{Conclusion}

The authors endeavoured to prove that some men, if not most of them, have been brought up in an environment that elevates men and devalues women. To these men it is a kind of life they live. They see nothing wrong in treating a woman as secondary and refusing her a leadership position. The law of equal rights to all human beings that is explicitly explicated in this article is not easily accepted by some of these men. Because some parts of the Bible elevate men above women, when literally interpreted, this sometimes exasperates the problem.

Since these men are negating female leadership or withholding their support for such leadership - because of cultural upbringing and an improper interpretation of scripture that is deemed discriminative by current law and government - such men need to be helped by being taught about the danger of defying the law and by causing tension in their churches, place of work and homes. They must also be taught about the benefit they can attain as a result of comradeship and cooperation between them and their female leaders or companions. Pastoral caregivers must rise up and take a strong stand against all forms of abuse and discrimination. They must become the voice of the voiceless. Just as much as some men are captives of patriarchy, so are some women because they were brought up from the same mould.

Some women are depressed as a result of experiencing betrayal from the men who elevated them to leadership positions yet withhold their support. Others cannot rise to high and expected leadership levels because of an inferiority complex due to their upbringing that leads them to believe that men are leaders and women are followers. Women who do not prove themselves capable of leading diminish the morale of women at large. To men it is a confirmation that women are weak and incapable of leading.

\section{Acknowledgements Competing interests}

The authors declare that they have no financial or personal relationship(s) which may have inappropriately influenced them in writing this article.

\section{Authors' contributions}

This article is an adaptation of G.H.S.'s (University of Pretoria) thesis, undertaken within the Department of Practical Theology at the University of Pretoria, as supervised by M.M. (University of Pretoria).

\section{References}

Baloyi, M.E., 2007, 'Patriarchal System a Hindrance to Women', Doctoral thesis, Dept. of Practical Theology, University of Pretoria, South Africa.

Brimohanlall, R., Foster, D.M., Gumede, B. \& Hicks, J., 1999, Making Women Rights Real, The gender manual consortium, Pretoria.

Campbell, A.V., 1986, Rediscovering Pastoral Care, Darton, Longman\& Todd Ltd, London.

Fiorenza, E.S., 2003, Walk in the Ways of Wisdom, Trinity Press International, Harrisburg.

Fiorenza, E.S., 1996, The Power of Naming, Orbis books, Maryknoll, New York.

Fiorenza, E.S., 1990, In Memory of Her - A Feminist Theological Reconstruction of Christian Origins, The Crossroads Publishing Company, New York.

Gerkin, C.V., 1997, An Introduction to Pastoral Care, Abingdon press, Nashville, TN.

Herman, J., 2001, Trauma and Recovery, Basic Book, New York.

Karant-Nunn, S.C \& Wiesner-Hanks, M.E., 2003, Luther on Women, Cambridge University Press, Cambridge.

Kung, H., 2001, Women in Christianity, Continuum books Co., New York.

Matlala, A., 2008, 'Woman Chief dents egos', Sowetan, 11 June, p. 3

Mickelsen, A.B., 1963, Interpreting the Bible, Eerdmans Publishing Co., Grand Rapids, MI.

Minister of Justice \& constitutional development, 2005 Constitution of the Republic of South Africa.

Nkotsoe, S.B., Phage, M.M., \& Rakgokong, M., 1998, Mosupatsela, Shuter \& Shooter (Pty) Ltd., Pietermaritzburg.

Phage M.M. \& Rakgokong, M., 1998, Mosupatsele, Shute \& shooter Publishers PTY, Pietermaritzburg.

Reuther, R.R., 1998, Women and Redemption, Augsburg Fortress Publishers, Minneapolis, MN.

Reuther, R.R., 1993, Sexism and God Talk, Beacon Press, Boston, MA.

Snyder, H.A. \& Runyon D.V., 1986, Foresight, Thomas Nelson Publishers, New York.

Waruta, D.W. \& Kinoti, W., 2000, Pastoral Care in African Christianity, Action Publishers, Nairobi.

Williams, D., 1978, The Apostle Paul and Women in the Church, Regal books division, $\mathrm{G} / \mathrm{L}$ Publishers, California.

'Women are equal', Daily Sun, 10 July, 2008, p. 15.

'Women at centre stage of Gauteng developments', Newsletter of the Gauteng Provincial Government, August 2008, p. 1, Gauteng Government Press, Johannesburg, RSA. 